\title{
Grass Hosts Harbor More Diverse Isolates of Puccinia striiformis Than Cereal Crops
}

\author{
P. Cheng, X. M. Chen, and D. R. See
}

First, second, and third authors: Department of Plant Pathology, Washington State University, Pullman 99164-6430; and second and third authors: U.S. Department of Agriculture-Agriculture Research Service, Wheat Genetics, Quality, Physiology and Disease Research Unit, Pullman, WA 99164-6430.

Accepted for publication 9 December 2015.

\begin{abstract}
Cheng, P., Chen, X. M., and See, D. R. 2016. Grass hosts harbor more diverse isolates of Puccinia striiformis than cereal crops. Phytopathology 106:362-371.

Puccinia striiformis causes stripe rust on cereal crops and many grass species. However, it is not clear whether the stripe rust populations on grasses are able to infect cereal crops and how closely they are related to each other. In this study, 103 isolates collected from wheat, barley, triticale, rye, and grasses in the United States were characterized by virulence tests and simple sequence repeat (SSR) markers. Of 69 pathotypes identified, 41 were virulent on some differentials of wheat only, 10 were virulent on some differentials of barley only, and 18 were virulent on some differentials of both wheat and

barley. These pathotypes were clustered into three groups: group one containing isolates from wheat, triticale, rye, and grasses; group two isolates were from barley and grasses; and group three isolates were from grasses and wheat. SSR markers identified 44 multilocus genotypes (MLGs) and clustered them into three major molecular groups (MG) with MLGs in MG3 further classified into three subgroups. Isolates from cereal crops were present in one or more of the major or subgroups, but not all, whereas grass isolates were present in all of the major and subgroups. The results indicate that grasses harbor more diverse isolates of $P$. striiformis than the cereals.

Additional keywords: microsatellite markers, population structure, yellow rust.
\end{abstract}

Stripe rust (yellow rust), caused by Puccinia striiformis Westend., an obligate, biotrophic, and dikaryotic fungus, is a major disease damaging wheat, barley, triticale, and rye; and also occurring on many grass species (Chen 2005; Stubbs 1985). In the literature, 320 species in 50 genera of the grass family Poaceae can be infected by P. striiformis (Hassebrauk 1965). According to the pathogen-host coevolution theory (Anderson and May 1982), the rust from wild grasses (high genetic diversity) could harbor more genetic variation than the ones from domestic common wheat (low genetic diversity) due to crop host selection.

The $P$. striiformis species is separated into several formae speciales based on their specialization on different host plants. The first group of five formae speciales of $P$. striiformis was reported by Eriksson (1894) based on host specificities, namely P. striiformis f. sp. tritici on wheat, P. striiformis f. sp. hordei on barley, P. striiformis f. sp. secalis on rye, $P$. striiformis f. sp. elymi on Elymus spp., and $P$. striiformis f. sp. agropyron on Agropyron spp. Since then, four more formae speciales have been reported: $P$. striiformis $\mathrm{f}$. sp. dactylidis on orchard grass (Dactylis glomerata L.) (Manners 1960; Tollenaar 1967), P. striiformis f. sp. poae on Kentucky bluegrass (Poa pratensis L.) (Tollenaar 1967), P. striiformis f. sp. leymi on Leymus secalinus (Niu et al. 1991), and P. striiformis f. sp. pseudo-hordei on wild barley grass (Hordeum spp.) (Wellings et al. 2000). The host specificity of $P$. striiformis f. sp. hordei, P. striiformis f. sp. tritici, and $P$. striiformis f. sp. poae (from bluegrass) were confirmed by greenhouse pathogenicity tests and the three formae speciales can

Corresponding author: X. M. Chen; E-mail address: xianming@wsu.edu

*The $\boldsymbol{e}$-Xtra logo stands for "electronic extra" and indicates that one supplementary figure and three supplementary tables are published online.

http://dx.doi.org/10.1094/PHYTO-07-15-0155-R

This article is in the public domain and not copyrightable. It may be freely reprinted with customary crediting of the source. The American Phytopathological Society, 2016. be separated from each other by random amplified polymorphic DNA analysis (Chen et al. 1995). Based on spore morphology and sequences of internal transcribed spacer (ITS) and beta-tubulin DNA regions, the stripe rust pathogens on bluegrass and orchard grass were described as different species, $P$. pseudostriiformis M. Abbasi, Hedjaroude, and M. Scholle and P. striiformoides M. Abbasi, Hedjaroude, and M. Scholle, respectively (Abbasi et al. 2004; Liu and Hambleton 2010).

In the United States, wheat stripe rust was first recognized in 1915 (Carleton 1915). The disease is most frequently destructive in the western United States, especially the Pacific Northwest and California, and since 2000 it has also become a serious production problem in states east of the Rocky Mountains (Chen 2007). Barley stripe rust, caused by $P$. striiformis f. sp. hordei, is a relatively new disease (Brown et al. 2001; Chen et al. 1995; Marshall and Sutton 1995; Roelfs et al. 1992). The severe wheat stripe rust epidemics and very low levels of barley stripe rust in recent years clearly show that the diseases are caused by different formae speciales of $P$. striiformis (Chen 2014; Chen et al. 2010; Wan and Chen 2014). The separation of P. striiformis f. sp. tritici and $P$. striiformis f. sp. horde $i$ were also supported by analysis of molecular markers (Chen et al. 1995). Therefore, P. striiformis f. sp. tritici races have been differentiated using a set of wheat genotypes and $P$. striiformis $\mathrm{f}$. sp. hordei races using a set of barley genotypes (Chen 2005; Chen et al. 1995; Wan and Chen 2012). Although $P$. striiformis f. sp. tritici mostly infects wheat and P. striiformis f. sp. hordei mostly infects barley, some wheat and barley genotypes have been found as common hosts for both formae speciales. Before $P$. striiformis f. sp. hordei was first detected in the United States in 1991 (Roelfs et al. 1992), stripe rust collected from barley, rye, triticale, and various grasses, except bluegrass and orchard grass, had been identified as the P. striiformis f. sp. tritici races commonly found in wheat fields (Line 2002; Line and Qayoum 1992). Since 1991, stripe rust samples from grasses (also except bluegrass and orchard grass) have 
been identified as $P$. striiformis f. sp. tritici or $P$. striiformis f. sp. hordei races, and sometimes as either $P$. striiformis f. sp. tritici or $P$. striiformis f. sp. hordei races because they were able to infect some differentials of both wheat and barley (Chen 2005; Chen et al. 2010).

The stripe rust pathogen is highly variable as demonstrated by both pathogenicity and molecular tests (Ali et al. 2014b; Bahri et al. 2009b; Mboup et al. 2009). Most previous pathogenicity and molecular characterization studies of $P$. striiformis have focused on the populations of wheat and/or barley (Bahri et al. 2009b; Chen et al. 1993, 1995; Duan et al. 2010; Enjalbert et al. 2005; Hovmøller and Justesen 2007; Hovmøller et al. 2002, 2011; Mboup et al. 2009; Steele et al. 2001; Zhan et al. 2012). Since P. striiformis was found to infect barberry (Berberis spp.) in 2010 (Jin et al. 2010), studies have been conducted to directly or indirectly determine the role of sexual stage on alternate hosts in pathogen epidemiology and genetic diversity (Ali et al. 2014a, b; Chen et al. 2012; Cheng and Chen 2014; Holtz et al. 2014; Rodriguez-Algaba et al. 2014; Wang and Chen 2015; Wang et al. 2015; Zhao et al. 2013). Stripe rust has been observed commonly on grasses. Although some early studies were conducted to determine the host range of $P$. striiformis on grasses and the possible role of host range in epidemics (Bever 1934; Dietz and Hendrix 1962; Hassebrauk 1965; Hovmøller et al. 2011), few studies have been conducted to genetically characterize $P$. striiformis on grasses. The present study was conducted to test the hypothesis. The specific objectives of this study were to (i) determine the pathogenicity diversity of $P$. striiformis isolates collected from various grasses and cereal crops, (ii) determine the genetic diversity of the grass isolates using codominant simple sequence repeat (SSR) markers, and (iii) determine the genetic relationships of the grass isolates with those from wheat and barley. The results of this study are useful in inferring the role of grasses in generating and maintaining genetic diversity of $P$. striiformis populations and in contribution to stripe rust epidemics on cereal crops.

\section{MATERIALS AND METHODS}

Isolate collection and spore reproduction. Among 103 P. striiformis isolates used in this study, 41 were collected from 13 species of wild grasses in the period from 2000 to 2008, 46 from wheat, 11 from barley, 4 from triticale, and 1 from rye. The isolates from wheat and barley were selected from the collections made between 2000 and 2008 as references for $P$. striiformis f. sp. tritici and $P$. striiformis f. sp. hordei, respectively, except six $P$. striiformis f. sp. tritici isolates representing historically important pathotypes (PST-1, PST-17, PST-21, PST-43, PST-45, and PST-59) from the 1960s to 1999 (Chen 2005; Line and Qayoum 1992). All the studied isolates were reproduced in the greenhouse either on wheat cultivar 'Nugaines' or 'Chinese 166', or barley cultivars 'Steptoe', following the standard procedures as previously described (Chen and Line 1992a, b). Nugaines does not have resistance in seedling stage to any P. striiformis f. sp. tritici races identified so far in the United States (Chen et al. 2002; Chen et al. 2010; Line and Qayoum 1992). Chinese 166 (with resistance gene $Y r 1$ ) is susceptible or moderately susceptible to some races of $P$. striiformis f. sp. hordei (Chen et al. 1995; Stubbs 1985). Steptoe is susceptible to all races of $P$. striiformis f. sp. horde $i$ and resistant to most $P$. striiformis $\mathrm{f}$. sp. tritici races (Chen et al. 1995, 2010). The single-spore isolates developed by Chen et al. (1993) were used for the six isolates representing the $P$. striiformis f. sp. tritici races before 2000 , and the remaining isolates were singleuredinium isolates. Harvested urediniospores were dried and kept in a desiccator at $4^{\circ} \mathrm{C}$ for less than 2 months and in liquid nitrogen for longer periods.

Pathogenicity tests. Pathogenicity of each isolate to wheat and barley were determined by using 20 wheat and 12 barley genotypes that are used to differentiate races of $P$. striiformis $\mathrm{f}$. sp. tritici and P. striiformis f. sp. hordei, respectively (Chen et al. 1995, 2002; Wan and Chen 2012). Fresh urediniospores or those kept in the desiccator at $4{ }^{\circ} \mathrm{C}$ for less than 2 months were used to inoculate the wheat and barley differential genotypes. Seedlings at two-leaf stage were dustinoculated with urediniospores mixed with talc (Sigma, Milwaukee, WI) at a ratio of 1:20. Inoculated plants were placed in a dew chamber for $24 \mathrm{~h}$ at $10^{\circ} \mathrm{C}$ without light and then moved to a growth chamber at a diurnal temperature cycle gradually changing from $4^{\circ} \mathrm{C}$ at 2:00 A.M. to $20^{\circ} \mathrm{C}$ at 2:00 P.M. with a 16-h light and 8-h dark cycle. To prevent cross contamination, plants inoculated with different isolates were separated by plastic booths. Infection types (IT) were recorded 18 to 20 days after inoculation using the 0 to 9 scale (Chen et al. 2002; Line and Qayoum 1992). In this study, we only had ITs 0 to 2 that were considered avirulent, and ITs 7 to 9 that were considered virulent. In our routine race identification work, $P$. striiformis f. sp. tritici races are determined by testing isolates only on the wheat differentials and $P$. striiformis f. sp. hordei races only on the barley differentials (Chen et al. 1995, 2002; Wan and Chen 2012). In this study, pathotypes, instead of races, were used to designate virulence phenotypes determined on both sets of wheat and barley differentials.

Detection of SSR markers. DNA was extracted from urediniospores following a modified protocol of DNA extraction (Aljanabi and Martinez 1997). DNA concentration was determined using a ND-1000 spectrophotometer (Bio-Rad, Hercules, CA), and the DNA samples were stored at $-20^{\circ} \mathrm{C}$. For PCR amplification, the stock DNA solution was diluted to $30 \mathrm{ng} / \mu \mathrm{l}$ as working solutions, and the diluted DNA samples were kept at $4{ }^{\circ} \mathrm{C}$. After initial screening, 20 SSR primer pairs with ability to detect homozygous and heterozygous loci as well as polymorphic alleles among five P. striiformis f. sp. tritici (PST-1, PST-21, PST-78, PST-100, and PST-127) and three P. striiformis f. sp. hordei (PSH-4, PSH-45, and PSH-72) races were selected to better characterize the dikaryotic fungus that can be treated as diploid. Of the 20 pairs of SSR primers, three (RJ18, RJ20, and RJ21) were developed from genomic DNA (Enjalbert et al. 2002) and 17 from expressed sequence tags (ESTs), including four (CPS02, CPS04, CPS08, and CPS13) developed by Chen et al. (2009), one (RJ8N) by Bahri et al. (2009a), and 12 (PstP001, PstP002, PstP003, PstP004, PstP005, PstP006, PstP007, PstP025, PstP029, PstP030, PstP031, and PstP033) by Cheng et al. (2012). In order to use fluorescence to detect polymerase chain reaction (PCR) products, an M13 tag (5'-CACGACGTTGTAAAACGAC) was added to the $5^{\prime}$ end of each forward primer (Schuelke 2000).

Each PCR reaction contained $1 \times \mathrm{PCR}$ buffer $(10 \mathrm{mM}$ Tris- $\mathrm{HCl}$ and $50 \mathrm{mM} \mathrm{KCl}$ ); $200 \mu \mathrm{M}$ of dCTP, dGTP, dTTP, and dATP; $1.5 \mathrm{mM}$ $\mathrm{MgCl}_{2} ; 5 \mathrm{pMol}$ tagged M13 fluorescent (Applied Biosystems, Foster City, CA); 1 pMol 5'-tagged forward primer; 5 pMol reverse primer; $1 \mathrm{U}$ of Taq polymerase (New England Biolabs, Ipswich, MA), and $0.75 \mathrm{ng}$ of DNA in a final volume of $12 \mu \mathrm{l}$. PCR was performed in an iCycler (Bio-Rad) thermal cycler (Watertown, MA) with the following profile: $94^{\circ} \mathrm{C}$ for $5 \mathrm{~min} ; 35$ cycles of $94^{\circ} \mathrm{C}$ for $30 \mathrm{~s}, 45$ to $57^{\circ} \mathrm{C}$ for $30 \mathrm{~s}$ (depending upon primer pair), and $72^{\circ} \mathrm{C}$ for $30 \mathrm{~s}$; and $72^{\circ} \mathrm{C}$ for $10 \mathrm{~min}$ followed by a $4^{\circ} \mathrm{C}$ holding step. Three microliters of PCR product was diluted to $25 \mu \mathrm{l}$ with $\mathrm{ddH}_{2} \mathrm{O}$. A total volume of $13 \mu \mathrm{l}$ containing $9 \mu \mathrm{l}$ of formamide, $1 \mu \mathrm{l}$ of DNA ladder (445-LIZ, Applied Biosystems), and $3 \mu \mathrm{l}$ of diluted PCR product was denatured at $95^{\circ} \mathrm{C}$ for $5 \mathrm{~min}$ and held at $4^{\circ} \mathrm{C}$. The sizes of the PCR fragments were estimated using capillary electrophoresis on an ABI3100 Genotyper (Applied Biosystems). To facilitate multiplex detection of SSR markers, PCR products amplified with four primer pairs tagged with FAM (blue), VIC (green), NED (yellow), and PET (red) were pooled into one ABI sample. Then PCR products of $3.0 \mu \mathrm{l}$ of FAM, $3.0 \mu \mathrm{l}$ of VIC, $4.0 \mu \mathrm{l}$ of NED and $6.0 \mu \mathrm{l}$ of PET were added into $9 \mu \mathrm{l}$ of $\mathrm{ddH}_{2} \mathrm{O}$ to get a $25-\mu$ l dilution. A total volume of $13 \mu$ l containing $9.93 \mu \mathrm{l}$ of formamide, $0.07 \mu \mathrm{l}$ of DNA ladder (445-LIZ, Applied Biosystems), and $3 \mu \mathrm{l}$ of diluted PCR product was denatured at $95^{\circ} \mathrm{C}$ for $5 \mathrm{~min}$ and held at $4{ }^{\circ} \mathrm{C}$. The internal molecular weight standard for the ABI3100 was Genescan 445-LIZ (Applied Biosystems). Alleles were called using GeneMapper v3.7 software.

Data analyses. For cluster analysis with the virulence data, avirulent ITs were converted to 0 and virulent ITs to 1 following the 
method of Chen et al. (1993, 1995). A similarity matrix based on simple match was generated using the SIMQUAL program, and a dendrogram (Fig. 1) was generated based on the matrix using the unweighted pair group arithmetic mean method in the NTsyspc 2.21 L program (Rohlf 2008). A similarity value of 0.75 , close to the middle of the similarity range, was used to arbitrarily cluster the pathotypes into groups.

The SSR data were used in all following molecular analyses. A neighbor-joining tree (Fig. 2) using the Dice similarity index was generated by transformed dissimilarity matrix using NTsyspc 2.21 L. Bootstrap analysis with 2,000 replicates was used to determine the robustness of branches of the dendrogram with Winboot (Nelson et al. 1994). Molecular groups (MGs) were determined based on the clusters and bootstrap values greater than 0.85 . To determine the frequencies of homozygous and heterozygous SSR loci and allele frequencies in each MG, the allele that had the higher frequency in the reference $P$. striiformis $\mathrm{f}$. sp. tritici isolates was designated as " $A$ " and the other allele as "B" for each SSR locus. The percentages of A and B alleles (Fig. 3A) and those of AA, AB, and BB genotypes (Fig. 3B) were compared for the MGs. Correlation between the SSR and virulence data were determined by comparison of the two similarity matrices using MXCOMP, a matrix comparison program of NTsyspc $2.21 \mathrm{~L}$. The analysis of molecular variance (AMOVA) and $F_{\text {st }}$ tests of five populations based on the host origin (wheat, barley, triticale, jointed goatgrass, and foxtail barley grass) with four or more isolates were conducted using GenAlex 6.05 (Peakall and Smouse 2012). To estimate the introgression between isolates from wheat, barley, and grasses, MIGRATE-N ver. 3.2.19 was used to calculate the migration rates $(M)$. The maximum likelihood estimations, theta $(\Theta=4 \mathrm{Ne} \mu)$, were determined using the Bayesian method in MIGRATE-N for microsatellite data (Beerli 2009).

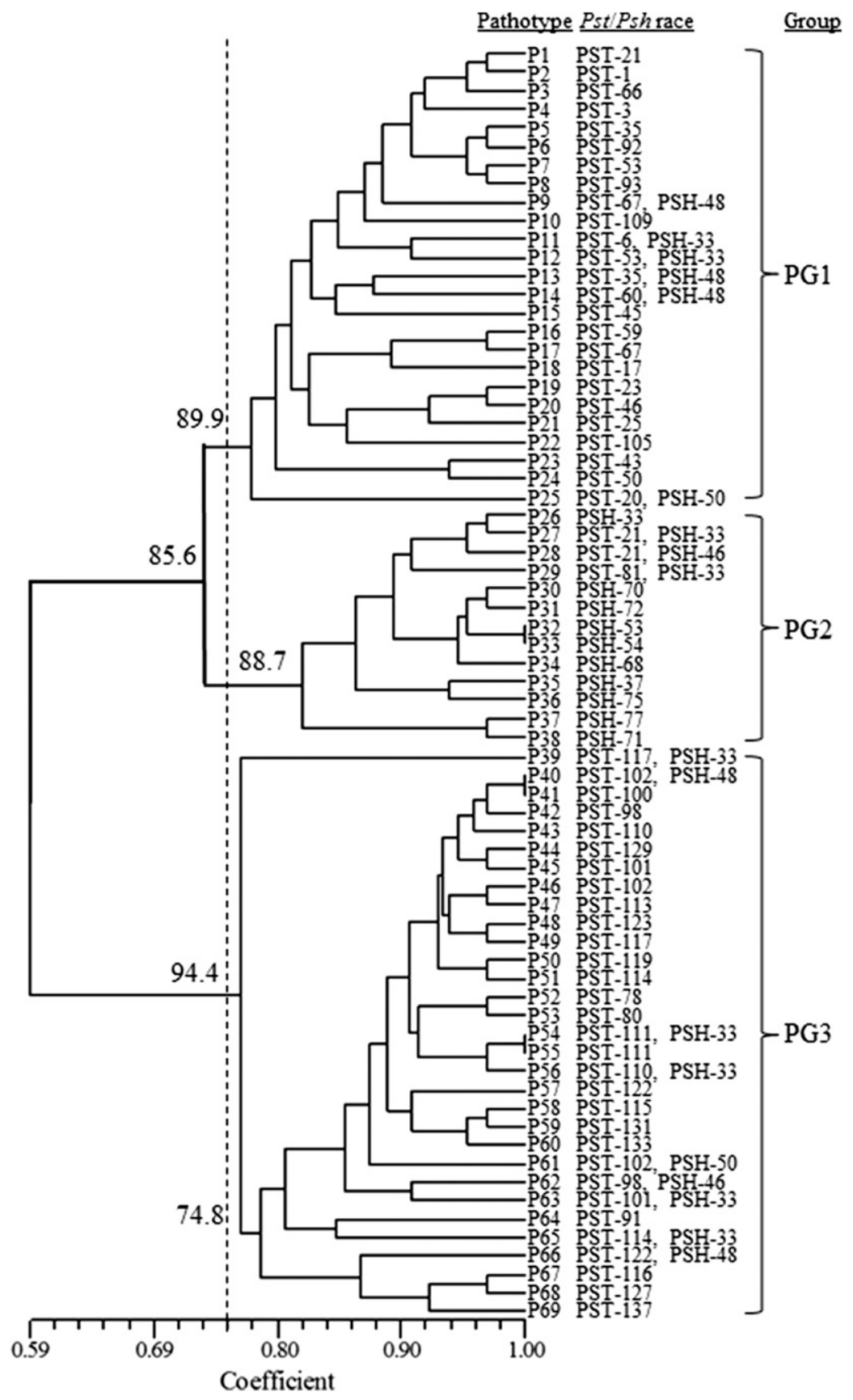

Fig. 1. Cluster analysis of the 69 identified pathotypes of Puccinia striiformis, their identified as P. striiformis f. sp. tritici (Pst) or P. striiformis f. sp. hordei (Psh) pathotypes, and the assigned pathotype groups. The number at each branch shows the percentage of times the group of isolates in that branch occurred based on 2,000 cycles in bootstrap analysis using the Winboot program (Nelson et al. 1994). 


\section{RESULTS}

Pathogenicity and virulence characterization. The one bluegrass isolate and two orchard grass isolates did not produce any symptoms (IT 0) on the 20 wheat and 12 barley differentials, and therefore, were considered $P$. peudostriiformis (syn. P. striiformis f. sp. poae) and P. striiformoides (syn. P. striiformis f. sp. dactylidis), respectively. As these three isolates were not pathogenic to either wheat or barley, they were excluded from virulence analysis. The 100 isolates from cereal crops and grasses were virulent (ITs 7 to 9) on some differentials of wheat and barley and were considered P. striiformis.

The isolates virulent on some differentials of only wheat were identified as $P$. striiformis $\mathrm{f}$. sp. tritici races and those virulent on

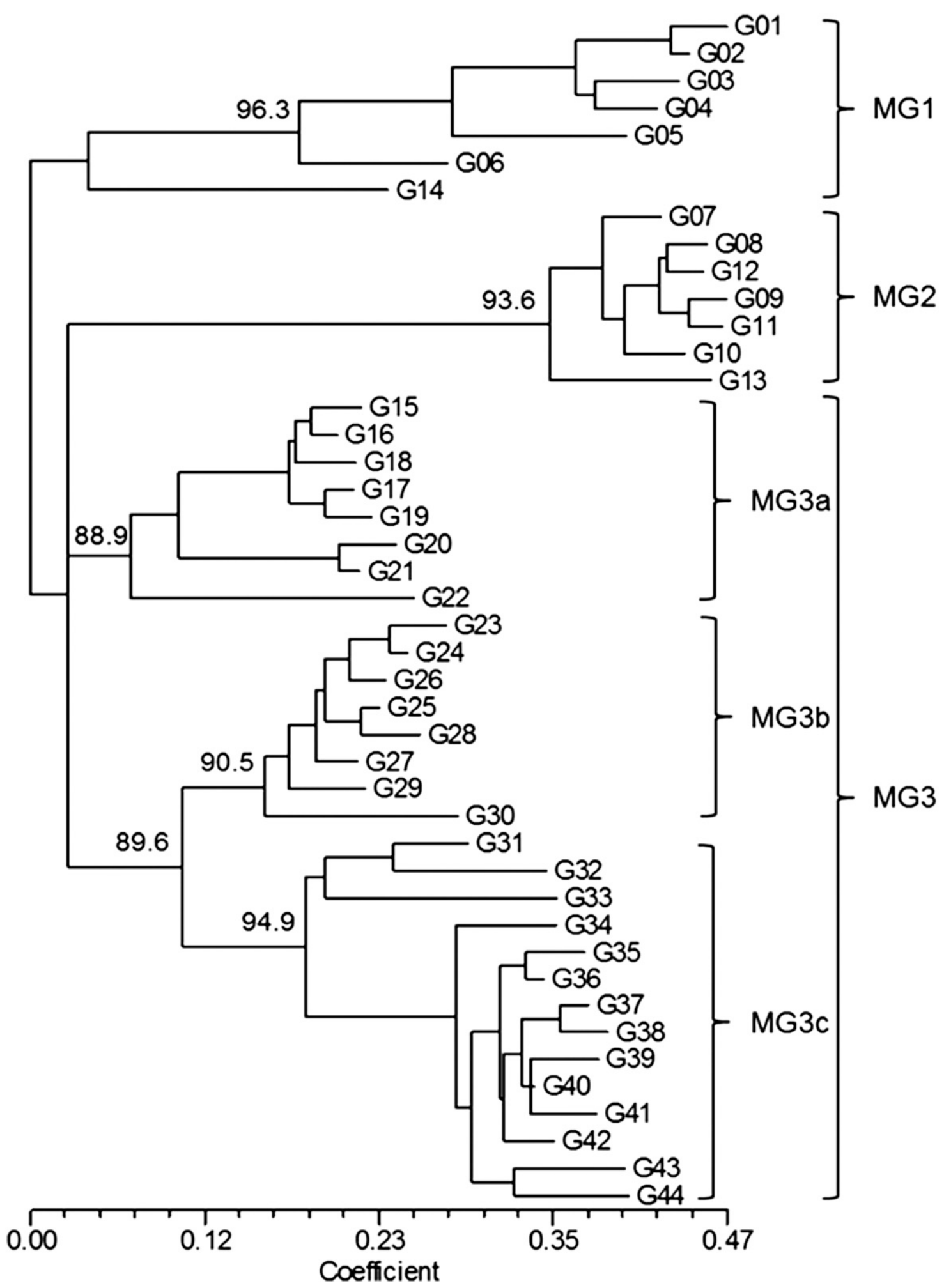

Fig. 2. Neighbor-joining tree of 44 molecular haplotypes of Puccinia striiformis based on simple sequence repeat marker data by NTsyspc $2.21 \mathrm{~L}$ program. MG1 to MG3 correspond to the molecular groups. The number at each branch shows the percentage of times the group of isolates in that branch occurred based on 2,000 cycles in bootstrap analysis using the Winboot program (Nelson et al. 1994). 
some differentials of only barley were identified as $P$. striiformis f. sp. hordei races, whereas the isolates virulent on some differentials of both wheat and barley could have a $P$. striiformis f. sp. tritici race name and a $P$. striiformis $\mathrm{f}$. sp. hordei race name. With one exception (isolate 06-223-N), the 46 isolates from wheat were identified as expected $P$. striiformis f. sp. tritici races and the 11 isolates from barley as $P$. striiformis f. sp. hordei races. The four isolates from triticale were identified as $P$. striiformis $\mathrm{f}$. sp. tritici races, except one isolate (04-146) collected in Oregon in 2004 that was identified as an either $P$. striiformis $\mathrm{f}$. sp. tritici race or P. striiformis f. sp. horde $i$ race. The only isolate collected from rye in California was identified as a predominant $P$. striiformis f. sp. tritici race, PST-100. The remaining 38 isolates, which were collected from various grasses, were identified as $P$. striiformis f. sp. tritici races (14 isolates) and either $P$. striiformis $\mathrm{f}$. $\mathrm{sp}$. tritici or $P$. striiformis $\mathrm{f}$. $\mathrm{sp}$. hordei races (24 isolates). The 14 isolates that were identified as P. striiformis f. sp. tritici races were from Hordeum jubatum or H. spontaneum (8), Aegilops cylindrica (2), Bromus biebersteinii
(1), Elymus fedtschenkoi (1), Pascopyrum smithii (1), and Pseudoroegneria spicata (1). The 24 isolates that were identified as either $P$. striiformis f. sp. tritici or $P$. striiformis f. sp. hordei races were from $H$. jubatum or $H$. spontaneum (8), Aegilops cylindrica (4), Agropyron cristatum (1), Avena fatua (2), B. biebersteinii (2), B. marginatus (3), E. glaucus (1), Pascopyrum smithii (1), and Pseudoroegneria spicata (2). These results indicate that various grass species can be infected by either $P$. striiformis f. sp. tritici or $P$. striiformis f. sp. hordei races.

To consider virulence data on both sets of wheat and barley differentials, pathotypes were used to designate the virulence patterns of the 100 isolates. The pathotypes and associated $P$. striiformis f. sp. tritici and/or P. striiformis f. sp. hordei races for the 100 isolates are provided in Supplementary Table S1. Based on the reactions on both sets of wheat and barley differentials, a total of 69 pathotypes (P1 to P69) were identified, and their virulence formulae are given in Table 1. Among the 69 pathotypes, 10 were virulent on some differentials of barley only; 41 were virulent on
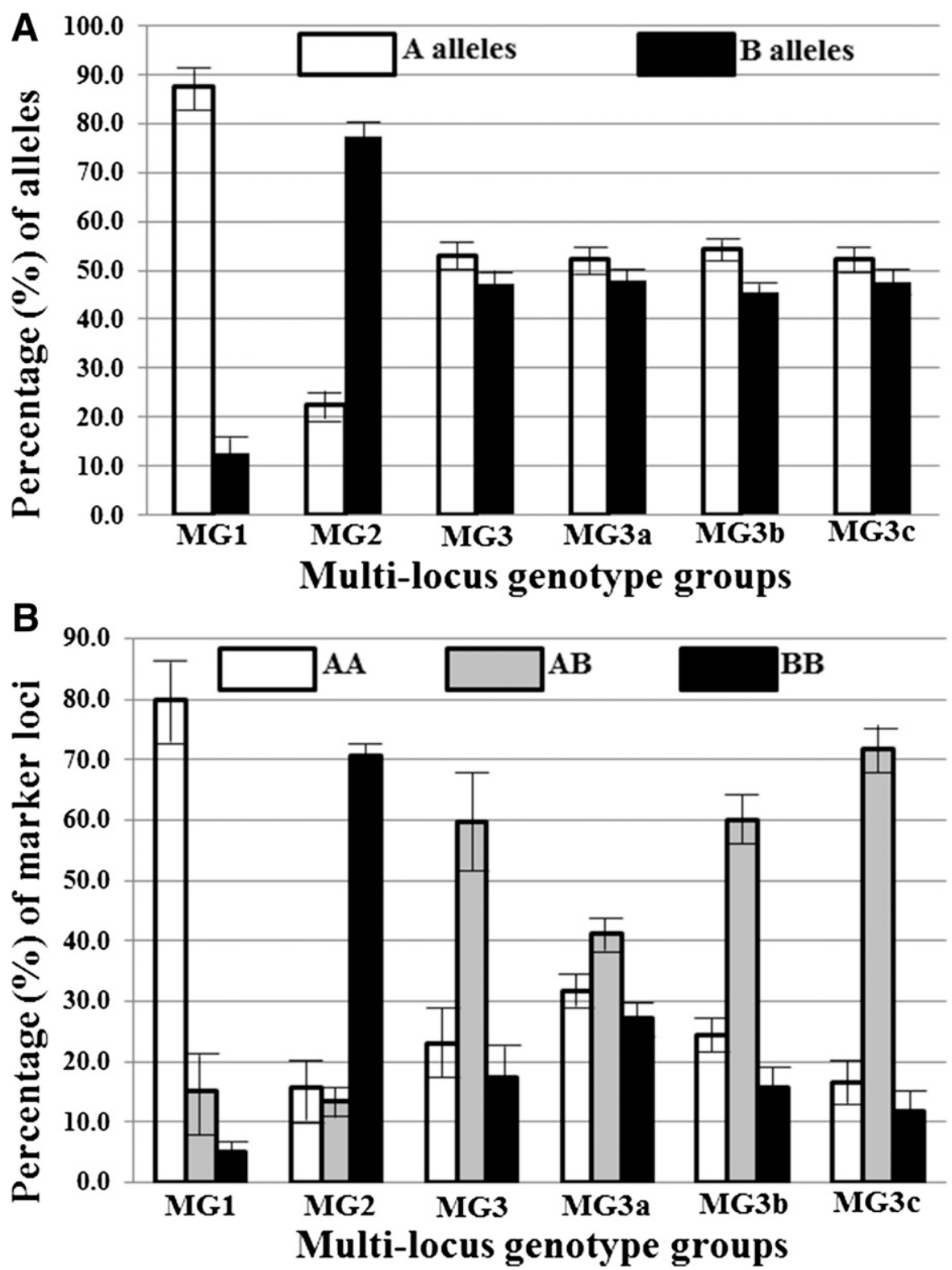

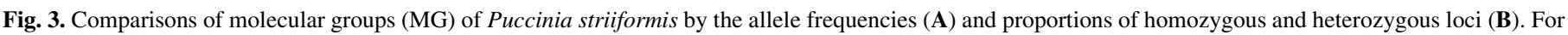

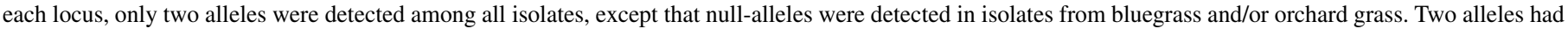

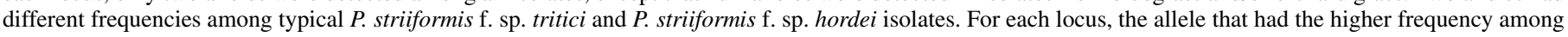

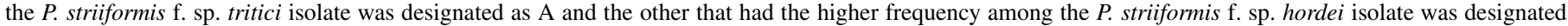
as B. 
TABLE 1. Pathotypes and Puccinia striiformis f. sp. tritici and P. striiformis f. sp. hordei races identified from isolates of $P$. striiformis collected from wheat, barley, triticale, rye, and various grasses

\begin{tabular}{|c|c|c|c|c|c|c|c|}
\hline \multirow[b]{2}{*}{ Pathotype } & \multicolumn{2}{|c|}{ Virulence formula ${ }^{a}$} & \multirow{2}{*}{$\begin{array}{l}\text { P. striiformis } \mathrm{f} \\
\text { sp. tritici race }\end{array}$} & \multirow{2}{*}{$\begin{array}{l}\text { P. striiformis } \mathrm{f} \text {. } \\
\text { sp. hordei race }\end{array}$} & \multicolumn{2}{|c|}{ Isolates } & \multirow{2}{*}{$\begin{array}{l}\text { Pathotype } \\
\text { group (PG) }\end{array}$} \\
\hline & Wheat differentials & Barley differentials & & & Number & Example & \\
\hline P1 & 2 & None & PST-21 & $N / A^{b}$ & 1 & PST-21 & PG1 \\
\hline $\mathrm{P} 2$ & 1,2 & None & PST-1 & N/A & 1 & PST-1 & PG1 \\
\hline P3 & $1,2,10,11,12,16$ & None & PST-66 & N/A & 1 & $00-140-\mathrm{N}$ & PG1 \\
\hline P4 & 1,3 & None & PST-3 & N/A & 1 & PST-3 & PG1 \\
\hline P5 & 1,10 & None & PST-35 & N/A & 1 & $00-139-\mathrm{N}$ & PG1 \\
\hline P6 & $1,10,12$ & None & PST-92 & N/A & 2 & $06-076-\mathrm{N}$ & PG1 \\
\hline P7 & $1,6,10$ & None & PST-53 & N/A & 1 & 07-137-6-sp1 & PG1 \\
\hline P8 & $1,6,10,12$ & None & PST-93 & N/A & 1 & 00-016 & PG1 \\
\hline P9 & $1,2,3,11,12,16$ & 1 & PST-67 & PSH-48 & 1 & 00-140-step & PG1 \\
\hline P10 & $1,4,8,10,12$ & None & PST-109 & N/A & 1 & $08-42$ & PG1 \\
\hline P11 & $1,6,8,12$ & 1,7 & PST-6 & PSH-33 & 1 & $04-063-S$ & PG1 \\
\hline $\mathrm{P} 12$ & $1,6,10$ & 1,7 & PST-53 & PSH-33 & 1 & 08-wo-N & PG1 \\
\hline $\mathrm{P} 13$ & 1,10 & 1 & PST-35 & PSH-48 & 1 & $00-139-S$ & PG1 \\
\hline P14 & $1,12,16$ & 1 & PST-60 & PSH-48 & 1 & $00-140-S$ & PG1 \\
\hline P15 & $1,3,12,13,15$ & None & PST-45 & N/A & 1 & PST-45 & PG1 \\
\hline P16 & $1,3,11,12,16$ & None & PST-59 & N/A & 1 & PST-59 & PG1 \\
\hline P17 & $1,2,3,11,12,16$ & None & PST-67 & N/A & 1 & $08-58-2$ & PG1 \\
\hline P18 & $1,2,3,9,11$ & None & PST-17 & N/A & 1 & PST-17 & PG1 \\
\hline P19 & $1,3,6,9,10$ & None & PST-23 & N/A & 1 & $08-70$ & PG1 \\
\hline $\mathrm{P} 20$ & $1,3,6,9,10,11$ & None & PST-46 & N/A & 1 & $08-223$ & PG1 \\
\hline P21 & $1,3,6,8,9,10,12$ & None & PST-25 & N/A & 1 & $08-12-3$ & PG1 \\
\hline $\mathrm{P} 22$ & $1,8,10,11,12,16,17,20$ & None & PST-105 & N/A & 2 & $06-035-\mathrm{N}$ & PG1 \\
\hline $\mathrm{P} 23$ & $1,3,4,5,12,14$ & None & PST-43 & N/A & 1 & PST-43 & PG1 \\
\hline P24 & $1,3,4,5,14$ & None & PST-50 & N/A & 1 & $05-316$ & PG1 \\
\hline P25 & $1,6,8,10,12$ & 1,5 & PST-20 & PSH-50 & 1 & $00-142-c-s$ & PG1 \\
\hline P26 & None & 1,7 & $N / A^{b}$ & PSH-33 & 1 & $08-114$ & PG2 \\
\hline P27 & 2 & 1,7 & PST-21 & PSH-33 & 6 & 08-JG & PG2 \\
\hline P28 & 2 & $1,7,8$ & PST-21 & PSH-46 & 1 & $08-145-S$ & PG2 \\
\hline P29 & 1,14 & 1,7 & PST-81 & PSH-33 & 1 & 00-071-S & PG2 \\
\hline $\mathrm{P} 30$ & None & $1,7,10,12$ & N/A & PSH-70 & 1 & $08-66$ & PG2 \\
\hline P31 & None & $1,2,3,4,5,6,7,8,9,10,11,12$ & N/A & PSH-72 & 1 & PSH-72 & PG2 \\
\hline P32 & None & $1,8,9$ & N/A & PSH-53 & 1 & PSH-53 & PG2 \\
\hline P33 & None & $1,7,8,12$ & N/A & PSH-54 & 1 & $08-140$ & PG2 \\
\hline P34 & None & $1,6,7,8,10,12$ & N/A & PSH-68 & 1 & $08-110$ & PG2 \\
\hline P35 & None & $1,2,4,7$ & N/A & PSH-37 & 1 & $08-137$ & PG2 \\
\hline P36 & None & $1,2,3,4,5,6,7,8,9,10,12$ & N/A & PSH-75 & 1 & PSH-75 & PG2 \\
\hline P37 & None & $1,3,5,7,8,9,10,12$ & N/A & PSH-77 & 1 & 08-169 & PG2 \\
\hline P38 & None & $1,3,5,6,7,8,9,10,12$ & N/A & PSH-71 & 1 & $08-275$ & PG2 \\
\hline P39 & $1,3,6,8,9,10,11,12,14,16,17,18,19,20$ & 1,7 & PST-117 & PSH-33 & 1 & $07-137$ & PG3 \\
\hline $\mathrm{P} 40$ & $1,3,8,9,10,11,12,14,16,17,18,19,20$ & 1 & PST-102 & PSH-48 & 1 & $06-223-\mathrm{N}$ & PG3 \\
\hline P41 & $1,3,8,9,10,11,12,16,17,18,19,20$ & None & PST-100 & N/A & 5 & PST-100 & PG3 \\
\hline $\mathrm{P} 42$ & $1,3,8,10,11,12,16,17,18,19,20$ & None & PST-98 & N/A & 3 & PST-98 & PG3 \\
\hline P43 & $1,3,8,9,11,12,16,17,18,19,20$ & None & PST-110 & N/A & 1 & $08-156$ & PG3 \\
\hline P44 & $1,2,3,8,10,11,12,16,17,18,19,20$ & None & PST-129 & N/A & 2 & $08-5-2$ & PG3 \\
\hline P45 & $1,2,3,8,9,10,11,12,16,17,18,19,20$ & None & PST-101 & N/A & 2 & $08-7$ & PG3 \\
\hline P46 & $1,3,8,9,10,11,12,14,16,17,18,19,20$ & None & PST-102 & N/A & 3 & $08-224$ & PG3 \\
\hline P47 & $1,2,3,8,9,10,11,12,14,16,17,18,19,20$ & None & PST-113 & N/A & 2 & $06-032-\mathrm{C}$ & PG3 \\
\hline P48 & $1,3,6,8,9,10,11,12,16,17,18,19,20$ & None & PST-123 & N/A & 2 & $08-165$ & PG3 \\
\hline P49 & $1,3,6,8,9,10,11,12,14,16,17,18,19,20$ & None & PST-117 & N/A & 3 & $08-164$ & PG3 \\
\hline P50 & $1,3,4,8,9,10,11,12,16,17,18,19,20$ & None & PST-119 & N/A & 1 & $08-179$ & PG3 \\
\hline P51 & $1,3,4,8,9,10,11,12,14,16,17,18,19,20$ & None & PST-114 & N/A & 2 & $08-253$ & PG3 \\
\hline P52 & $1,3,11,12,16,17,18,19,20$ & None & PST-78 & N/A & 1 & PST-78 & PG3 \\
\hline P53 & $1,3,8,11,12,16,17,18,19,20$ & None & PST-80 & N/A & 1 & PST-80 & PG3 \\
\hline P54 & $1,3,5,8,10,11,12,16,17,18,19,20$ & 1,7 & PST-111 & PSH-33 & 1 & $05-469$ & PG3 \\
\hline P55 & $1,3,5,8,10,11,12,16,17,18,19,20$ & None & PST-111 & N/A & 2 & $08-124$ & PG3 \\
\hline P56 & $1,3,8,9,11,12,16,17,18,19,20$ & 1,7 & PST-110 & PSH-33 & 2 & 08-B2 & PG3 \\
\hline P57 & $1,2,3,6,8,9,10,11,12,14,16,17,18,19,20$ & None & PST-122 & N/A & 1 & $01-120$ & PG3 \\
\hline P58 & $1,3,5,8,9,10,11,12,14,16,17,18,19,20$ & None & PST-115 & N/A & 3 & $08-269$ & PG3 \\
\hline P59 & $1,3,5,6,8,9,10,11,12,14,16,17,18,19,20$ & None & PST-131 & N/A & 1 & $08-252$ & PG3 \\
\hline P60 & $1,2,3,5,6,8,9,10,11,12,14,16,17,28,29,20$ & None & PST-133 & N/A & 2 & $08-237$ & PG3 \\
\hline P61 & $1,3,8,9,10,11,12,14,16,17,18,19,20$ & 1,5 & PST-102 & PSH-50 & 1 & $00-142-S$ & PG3 \\
\hline P62 & $1,3,8,10,11,12,16,17,18,19,20$ & $1,7,8$ & PST-98 & PSH-46 & 1 & $07-179-S$ & PG3 \\
\hline P63 & $1,2,3,8,9,10,11,12,16,17,18,19,20$ & 1,7 & PST-101 & PSH-33 & 2 & $08-121-\mathrm{N}$ & PG3 \\
\hline P64 & $1,9,10$ & None & PST-91 & N/A & 1 & $06-058-\mathrm{N}$ & PG3 \\
\hline P65 & $1,3,4,8,9,10,11,12,14,16,17,18,19,20$ & 1,7 & PST-114 & PSH-33 & 2 & $08-268$ & PG3 \\
\hline P66 & $1,2,3,6,8,9,10,11,12,14,16,17,18,19,20$ & 1 & PST-122 & PSH-48 & 1 & $00-141-\mathrm{N}$ & PG3 \\
\hline P67 & $1,3,4,5,8,9,10,11,12,14,16,17,18,19,20$ & None & PST-116 & N/A & 1 & 08-308-6-sp1 & PG3 \\
\hline P68 & $1,2,3,5,6,8,9,10,11,12,13,15,16,17,18,19,20$ & None & PST-127 & N/A & 2 & PST-127 & PG3 \\
\hline P69 & $1,2,3,5,6,8,9,10,12,13,15,17,18,19,20$ & None & PST-137 & N/A & 2 & 06-030-C & PG3 \\
\hline
\end{tabular}

${ }^{a}$ P. striiformis f. sp. tritici races were based on wheat differential cultivars: $1=$ Lemhi $(Y r 21), 2=$ Chinese $166(Y r 1), 3=$ Heines VII $(Y r 2, Y r H V I I), 4=\mathrm{Moro}$

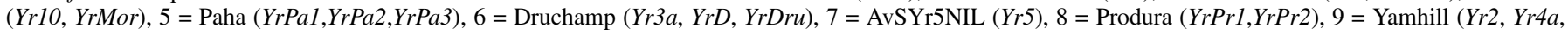
YrYam $), 10=$ Stephens $(Y r 3 a, Y r S, Y r S t e), 11=$ Lee $(Y r 7, Y r 22, Y r 23), 12=$ Fielder $(Y r 6, Y r 20), 13=$ Tyee $(Y r T y e), 14=\operatorname{Tres}(Y r T r 1, Y r T r 2), 15=\operatorname{Hyak}(Y r 17$,

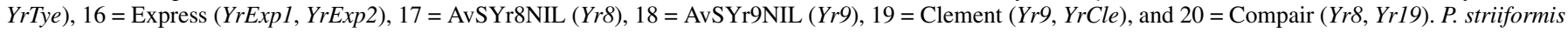
f. sp. hordei races were based on barley differential cultivars: $1=$ Topper (none), $2=$ Heils Franken $(R p s 4, r p s H F), 3=$ Emir $(r p s E m, r p s E m 2), 4=$ Astrix $(R p s 4$, $r p s A s t), 5=$ Hiproly $(r p s H i 1, r p s H i 2), 6=$ Varunda $(r p s V a 1, r p s V a 2), 7=$ Abed Binder $12(r p s 2), 8=$ Trumpf $(r p s T r 1, r p s T r 2), 9=\operatorname{Mazurka}($ Rps $1 . c), 10=$ Bigo (Rps1.b), $11=\mathrm{I} 5$ (Rps3, rpsI5), and 12 = Bancroft (RpsBa) (Wan and Chen 2012). In each virulence formula, the missing numbers indicate that the isolate was avirulent on the differentials.

b N/A: no visible infection on the plants. 
some differentials of wheat only; and 18 were either $P$. striiformis f. sp. tritici or P. striiformis f. sp. hordei races that were virulent on some differentials of both wheat and barley.

When the 69 pathotypes were analyzed by plant origin of initial isolation, 27 pathotypes were comprised of isolates from wheat only, 11 from barley only, one from triticale only, 24 from grasses only, four from both wheat and grasses, one consisting of isolates from both triticale and grasses, and one containing isolates from wheat, rye, and grasses (Table 2). These results indicate that the
P. striiformis populations of various grasses vary wider in virulence than the commonly grown cereal crops, wheat and barley, and also indicate that the pathogen from grasses has a tendency to infect both wheat and barley.

The 69 pathotypes were clustered into three pathotype groups (PGs) (Fig. 1). PG1 comprised of 25 pathotypes (P1 to P25) collected from Aegilops cylindrica, Avena fatua, B. biebersteinii, H. jubatum, Pascopyrum smithii, Pseudoroegneria spicata, and Triticosecale spp., as well as selected reference $P$. striiformis f. sp.

TABLE 2. Number of pathotypes of Puccinia striiformis identified among isolates from various cereal and grass hosts

\begin{tabular}{|c|c|c|c|}
\hline \multirow[b]{2}{*}{ Host origin } & \multicolumn{2}{|r|}{ Pathotypes } & \multirow[b]{2}{*}{ Pathotype group (PG) (number of pathotypes) } \\
\hline & Number & Pathotypes & \\
\hline Wheat only & 27 & $\begin{array}{l}\text { P2, P4, P10, P15, P16, P17, P18, P19, P20, P21, P23, } \\
\text { P42, P43, P44, P45, P46, P49, P50, P51, P52, P53, P55, } \\
\text { P58, P59, P60, P67, P68 }\end{array}$ & PG1 (11), PG3 (16) \\
\hline Barley only & 11 & P26, P30, P31, P32, P33, P34, P35, P36, P37, P38, P40 & PG2 (10), PG3 (1) \\
\hline Triticale only & 1 & $\mathrm{P} 1$ & PG1 (1) \\
\hline Grasses only & 24 & $\begin{array}{l}\mathrm{P} 3, \mathrm{P} 5, \mathrm{P} 7, \mathrm{P} 8, \mathrm{P} 9, \mathrm{P} 11, \mathrm{P} 12, \mathrm{P} 13, \mathrm{P} 14, \mathrm{P} 22, \mathrm{P} 24, \mathrm{P} 25, \mathrm{P} 27, \\
\mathrm{P} 28, \mathrm{P} 29, \mathrm{P} 39, \mathrm{P} 54, \mathrm{P} 56, \mathrm{P} 57, \mathrm{P} 61, \mathrm{P} 62, \mathrm{P} 64, \mathrm{P} 65, \mathrm{P} 66\end{array}$ & PG1 (12), PG2 (3), PG3 (9) \\
\hline Wheat and barley & 0 & 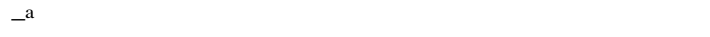 & - \\
\hline Wheat and triticale & 0 & - & - \\
\hline Wheat and grasses & 4 & P6, P47, P48, P69 & PG1 (1), PG3 (3) \\
\hline Barley and triticale & 0 & - & - \\
\hline Barley and grasses & 0 & - & - \\
\hline Triticale and grasses & 1 & P63 & PG3 (1) \\
\hline Wheat, barley, and triticale & 0 & - & - \\
\hline Wheat, rye, and grasses & 1 & P41 & PG3 (1) \\
\hline Barley, triticale, and grasses & 0 & - & - \\
\hline All cereals and grasses & 0 & - & - \\
\hline Total & 69 & & $(69)$ \\
\hline
\end{tabular}

a Not detected.

TABLE 3. Number of multilocus genotypes identified among isolates from various cereal and grass hosts of Puccinia striiformis

\begin{tabular}{|c|c|c|c|}
\hline \multirow[b]{2}{*}{ Host origin } & \multicolumn{2}{|r|}{ Multilocus genotypes } & \multirow[b]{2}{*}{ Molecular group (MG) } \\
\hline & Number & Genotypes & \\
\hline Wheat only & 11 & G1, G4, G15, G19, G30, G34, G35, G36, G39, G43, G44 & MG1, MG3a, MG3b, MG3c \\
\hline Barley only & 6 & G9, G10, G11, G12, G13, G37 & MG2, MG3c \\
\hline Triticale only & 2 & G5, G33 & MG1, MG3c \\
\hline Grasses only & 15 & $\begin{array}{l}\text { G6, G7, G14, G20, G21, G22, G23, G24, } \\
\text { G28, G29, G31, G32, G38, G41, G42 }\end{array}$ & MG1, MG2, MG3a, MG3b, MG3c \\
\hline Wheat and barley & 0 & - a & - \\
\hline Wheat and triticale & 0 & - & - \\
\hline Wheat and grasses & 5 & $\mathrm{G} 2, \mathrm{G} 16, \mathrm{G} 17, \mathrm{G} 18, \mathrm{G} 40$ & MG1, MG3a, MG3c \\
\hline Barley and triticale & 0 & - & - \\
\hline Barley and grasses & 2 & G8, G27 & MG2, MG3b \\
\hline Triticale and grasses & 1 & G3 & MG1 \\
\hline Rye and grasses & 1 & G26 & MG3b \\
\hline Wheat, barley and triticale & 0 & - & - \\
\hline Barley, triticale and grasses & 1 & G25 & MG3b \\
\hline All cereals and grasses & 0 & - & - \\
\hline Total & 44 & & \\
\hline
\end{tabular}

a Not detected.

TABLE 4. Analysis of molecular variance among host origins (populations) and individual isolates of Puccinia striiformis

\begin{tabular}{|c|c|c|c|c|c|c|}
\hline Source $^{a}$ & $\mathrm{df}^{\mathrm{b}}$ & $\mathrm{SS}^{\mathrm{c}}$ & $\mathrm{MS}^{\mathrm{d}}$ & Estimated variance & Variance $(\%)$ & $P^{\mathrm{e}}$ \\
\hline Among populations & 4 & 147.31 & 36.83 & 2.33 & 27 & $<0.001$ \\
\hline Within populations & 78 & 492.73 & 6.32 & 6.32 & 73 & $<0.001$ \\
\hline Total & 82 & 640.04 & 43.15 & 8.64 & 100 & \\
\hline
\end{tabular}

a A total of 83 isolates from five host origins (wheat, barley, triticale, joint goatgrass, and foxtail) as populations with four or more isolates were analyzed.

$\mathrm{b}$ df $=$ degree of freedom.

c $\mathrm{SS}=$ sum of squares.

d $\mathrm{MS}=$ mean square.

e $P=$ probability value. 
tritici isolates collected from wheat. PG2 contained 13 pathotypes (P26 to P38) collected from H. jubatum, Aegilops cylindrica, and Avena fatua, in addition to the selected P. strifformis f. sp. hordei reference isolates collected from barley. The 31 pathotypes in PG3 were collected from Agropyron cristatum, Aegilops cylindrica, B. biebersteinii, B. marginatus, E. fedtschenkoi, E. glaucus, H. jubatum, Triticosecale, and $S$. cereal, as well as from wheat. The results showed that isolates from grasses were present in all of the three PGs. In contrast, isolates from wheat were present in two groups and those from barley mostly in one group.

Molecular characterization. Using the 20 SSR markers, 44 multilocus genotypes (MLGs) were identified from the 100 $P$. striiformis isolates and three MLGs (P. striiformis $\mathrm{f}$. sp. dactylidis $1, P$. striiformis $\mathrm{f}$. sp. dactylidis 2 , and $P$. striiformis $\mathrm{f}$. sp. poae 1 ) from the three isolates collected from bluegrass or orchard grass. The alleles of the 44 P. striiformis MLGs (G1 to G44) are given in Supplementary Table S2. The three isolates collected from bluegrass or orchard grass were excluded from further analyses because three markers were not detected in any and five were not detected in one or two of the three isolates, indicating different formae speciales or species.

The neighbor-joining tree generated with the SSR data clustered the 44 MLGs into three MGs (Fig. 2). MG1 and MG2 each consisted of seven MLGs, whereas MG3 consisted of 30 MLGs. MG3 was further separated into three subgroups, MG3a with eight MLGs, MG3b with eight MLGs, and MG3c with 14 MLGs.

When the MLGs were organized by their host origins, we found that 11 MLGs were from wheat only, six MLGs from barley only, 15 MLGs from grasses only, five MLGs from both wheat and grasses, and two MLGs from barley and grasses (Table 3). The MLGs from wheat were present in MG1, MG3a, MG3b, and MG3c, but not in MG2. The MLGs from barley were present in MG2, MG3b, and MG3c, but not in MG1 and MG3a. The MLGs from grasses were

TABLE 5. Pairwise comparisons of $F_{\text {st }}$ and $\operatorname{Lin} F_{\text {st }}$ values between five populations of Puccinia striiformis of different host origins

\begin{tabular}{|c|c|c|c|c|c|}
\hline \multicolumn{2}{|c|}{ Populations (number of isolates) ${ }^{\mathrm{a}}$} & \multirow[b]{2}{*}{$F_{\text {st }}$} & \multirow[b]{2}{*}{$\operatorname{Lin} F_{\text {st }}$} & \multirow[b]{2}{*}{$\mathrm{Nm}^{\mathrm{b}}$} & \multirow[b]{2}{*}{$P^{\mathrm{c}}$} \\
\hline Population 1 & Population 2 & & & & \\
\hline Joint goatgrass (6) & Foxtail (16) & 0.000 & 0.000 & N/A & 0.397 \\
\hline Foxtail (16) & Triticale (4) & 0.042 & 0.044 & 5.639 & 0.160 \\
\hline Triticale (4) & Wheat (46) & 0.055 & 0.058 & 4.309 & 0.140 \\
\hline Joint goatgrass (6) & Wheat (46) & 0.043 & 0.045 & 5.507 & 0.125 \\
\hline Joint goatgrass (6) & Triticale (4) & 0.065 & 0.070 & 3.590 & 0.118 \\
\hline Joint goatgrass (6) & Barley (11) & 0.102 & 0.114 & 2.191 & 0.027 \\
\hline Foxtail (16) & Wheat (46) & 0.057 & 0.060 & 4.168 & 0.007 \\
\hline Barley (11) & Triticale (4) & 0.305 & 0.438 & 0.571 & 0.002 \\
\hline Barley (11) & Foxtail (16) & 0.192 & 0.238 & 1.052 & 0.001 \\
\hline Barley (11) & Wheat (46) & 0.272 & 0.374 & 0.668 & 0.001 \\
\hline
\end{tabular}

a A population is referred to isolates collected from a single plant species: joint goatgrass = Aegilops cylindrica; foxtail = Hordeum jubatum and $H$. spontaneum; wheat $=$ Triticum aestivum $;$ triticale $=$ Triticosecale $\mathrm{spp}$; and barley $=H$. vulgare.

b $\mathrm{Nm}=$ number of effective migrants.

c Probability, for $F_{\text {st }}, \operatorname{Lin} F_{\text {st }}$ is based on standard permutation across the full data set. present in all major and subgroups (MG1, MG2, MG3a, MG3b, and MG3c). These results indicate that the isolates from grasses are more diverse than isolates from either wheat or barley.

The proportions of homozygous versus heterozygous loci and allele frequencies in each MG are presented in Figure 3. For the two alleles at each locus, if the allele present in the higher frequency in the reference $P$. striiformis $\mathrm{f}$. sp. tritici isolates was designated as "A" and that in higher frequency in the reference $P$. striiformis $\mathrm{f}$. sp. hordei isolates as "B", an isolate could be determined to have more $P$. striiformis f. sp. tritici alleles or P. striiformis f. sp. hordei alleles (Supplementary Fig. S1). The percentages of A and B alleles and the percentages of $\mathrm{AA}, \mathrm{AB}$, and $\mathrm{BB}$ genotypes for each MLG can be found in Supplementary Table S3. As shown in Figure 3, MG1 had more A alleles ( $>80 \%)$, MG2 had more B alleles ( $>70 \%)$, and MG3 had relatively balanced A and B alleles (Fig. 3A). MG1 had much higher homozygous AA loci and MG2 had much higher homozygous BB loci, whereas MG3 had higher heterozygous (AB) loci than either of the homozygous AA or BB loci, especially MG3c (Fig. 3B). The differences in both allele frequency and genotype frequency across the SSR marker loci were significant $(P<0.0001)$, indicating that allele frequency and homozygosity/ heterozygosity could be used to distinguish the genetic lineages.

The AMOVA test showed relatively low variation among populations based on host origins (wheat, barley, triticale, joint goatgrass, and foxtail) (27\%) and high variation within populations $(73 \%)$ (Table 4). In spite of the different percentages, both variation components contributed significantly to the overall variation $(P<$ $0.001)$. Both levels of variation in pairwise comparisons between populations based on genetic differentiation $F_{\mathrm{ST}}$ and $\mathrm{Lin} F_{\mathrm{ST}}$ values showed that isolates collected from grasses and triticale were not significantly differentiated from those of wheat $(P>0.10)$, but significantly differentiated from those of barley $(P<0.05)$. Similarly, barley isolates were significantly differentiated from those collected from wheat $(P=0.001)$ (Table 5), indicating more specificity between populations of barley and wheat or grasses, but less differentiation between populations of wheat and grasses. These conclusions were supported by the relatively high number of effective migrants between the wheat and grass populations and the relatively low number between the barley population and the wheat and grass populations (Table 5).

When the direction of migration between $P$. striiformis populations was concerned, maximum likelihoods of migration rates among isolates from different hosts were estimated (Table 6). Higher migration rates were found from cereal crops (wheat or barley) to grasses than from grasses to wheat. Between the wheat and barley populations, migration was higher from wheat to barley than from barley to wheat. The lowest migration rate was found from grass to barley (0.96), and the highest (1.24) from wheat to grasses.

Correlation of molecular genotypes and virulence phenotypes. The correlation analysis of the molecular and virulence data showed a moderate, but highly significant correlation coefficient $(r=0.54$; $P<0.01$ ). Many isolates in MG1, MG2, and MG3 (Fig. 2) belonged to PG1, PG2, and PG3 (Fig. 1), respectively. The moderate correlation was partially related to the origin of the isolates as

TABLE 6. Mutation-scaled population sizes $(\Theta)$ and migration rates $(M)$ among the Puccinia striiformis populations from wheat, barley, and grasses based on the simple sequence repeat data

\begin{tabular}{|c|c|c|c|c|}
\hline \multirow[b]{3}{*}{ Recipient population } & \multirow[b]{3}{*}{$\Theta^{\mathrm{a}}$} & \multicolumn{3}{|c|}{ Migration rate } \\
\hline & & \multicolumn{3}{|c|}{ Source population } \\
\hline & & Wheat & Barley & Grasses \\
\hline Barley & $0.70(0.60,0.80)$ & $1.14(0.97,1.31)$ & & $0.96(0.79,1.13)$ \\
\hline Grasses & $0.92(0.22,1.62)$ & $1.24(1.06,1.42)$ & $1.10(0.93,1.27)$ & \\
\hline
\end{tabular}

${ }^{a}$ Maximum likelihood estimates of migration rates $(M=m / \mu)$ and $95 \%$ confidence intervals (parentheses) were calculated using MIGRATE-N 3.2.19 (Beerli 2009). 
isolates from barley were mostly in MG2 or PG2, and isolates of wheat and grasses were mostly in MG1 and MG3 or PG1 and PG3.

\section{DISCUSSION}

The stripe rust fungus infects cereal crops and various grasses. However, previous studies on genetic diversity have been mostly on the populations of wheat and to a less extent on those of barley, due to economic importance of the stripe rust diseases on the two main cereal crops. The information of genetic diversity in P. striiformis populations on grasses has been limited. In the present study, we determined genetic diversity of $P$. striiformis isolates collected from 13 host species in 10 genera and compared them with isolates from wheat, barley, triticale, and rye using virulence tests and SSR markers. Both pathogenicity and SSR marker tests separated the stripe rust isolates from bluegrass and orchard grass from those of other grasses and cereal crops. These results are in agreement with previous studies and support separation them as formae speciales or species different from those on wheat and barley (Abbasi et al. 2004; Chen et al. 1995; Liu and Hambleton 2010). Because only three isolates from bluegrass and orchard grass were used in the present study, the genetic diversities in these populations could not be determined. Further studies using a large number of isolates from bluegrass and orchard grass are needed to confirm the distinction of the stripe rust populations on these grasses from those on other grasses and cereal crops and determine if they play any role in stripe rust epidemics on cereal crops.

Because of the limited number of isolates, we were not able to determine the existence of $P$. striiformis f. sp. secales, $P$. striiformis f. sp. elymi, and P. striiformis f. sp. agropyron as reported by Eriksson (1894). However, we found that all four isolates from triticale and one isolate from rye were of $P$. striiformis $\mathrm{f}$. sp. tritici, and those isolates were identified as the common $P$. striiformis $\mathrm{f}$. sp. tritici races detected in wheat fields (Chen et al. 2010; Wan and Chen 2012). The isolates from Agropyron and Elymus species were identified as P. striiformis f. sp. tritici or P. striiformis f. sp. hordei races. Similarly, the isolates from other grass species were also $P$. striiformis $\mathrm{f}$. sp. tritici or both $P$. striiformis f. sp. tritici and $P$. striiformis f. sp. hordei. Therefore, our results do not support formae speciales of $P$. striiformis f. sp. secales, $P$. striiformis f. sp. elymi, and $P$. striiformis f. sp. agropyron, but show that these grass species are hosts of $P$. striiformis f. sp. tritici and P. striiformis f. sp. hordei.

In the present study, we identified a higher diversity of genetic variation among the isolates from grasses than those from cereals. The isolate/pathotype ratio of the cereal crop population was 1.38:1, whereas the ratio of the grass population was 1.27:1. The isolates collected from barley were mostly grouped in one PG and those from wheat in two PGs, whereas the isolates from grasses were in all three groups. Similarly, the isolate:MLG ratio of the cereal crop population was $2.14: 1$, whereas the ratio of the grass population was 1.52:1. Therefore, both pathogenicity and molecular results indicate that grass hosts harbor more diverse $P$. striiformis populations than the cereal crop hosts. These ratios show the differences in genetic diversity for the stripe rust pathogen populations on grasses and cereal crops based on the isolates used in the present study. Further studies using a large number of isolates collected systematically are needed to confirm the results.

The relatively high diversity among the grass isolates could be due to the lack or low selection of grasses. In contrast, stripe rust resistance in wheat and barley cultivars can place selection pressure to the pathogen population, and thus reduce the diversity. The avirulent isolates may evolve into virulent races to overcome racespecific resistance in cultivars of cereal crops. Over the past several decades, new races that have a relatively narrow virulence spectrum and do not have very close relationships with previously existing races in wheat fields have been often identified from wheat cultivars (Chen 2005; Chen et al. 2010; Line and Qayoum 1992). Such new races could have been evolved from isolates on grasses. Thus, it is important to conduct virulence tests for stripe rust samples from grasses.

The codominant SSR markers allowed us to identify homozygous and heterozygous loci and determine their proportions across all SSR loci. Major molecular groups MG1 and MG2 were distinguishable by their much different proportions of two different homozygous alleles, and MG3 was distinguished from both MG1 and MG2 by its much higher proportion of heterozygous loci. The three subgroups (MG3a, MG3b, and MG3c) in MG3 group were also separated by their relatively low (41\%), intermediate $(60 \%)$, and high $(72 \%)$ heterozygous loci. The major molecular groups were similar to those in the previous studies using gene sequences (Liu et al. 2012) and SSR markers (Cheng and Chen 2014).

As shown in the present study, grasses serve as hosts for the stripe rust fungi of cereal crops. Grasses may provide initial inoculum for initiating stripe rust epidemic in wheat and barley crops or add inoculum for increasing disease pressure depending upon climatic conditions and cropping systems. The role of providing inoculum for infection of cereal crops is supported by the detection of pathotypes that are predominant races in wheat or barley fields in the present study (Chen et al. 2010; Wan and Chen 2012). In addition, we also detected a large number of isolates that were not detected in wheat or barley fields. These results let us speculate that grasses serve as reservoirs for maintaining genetic diversity for the stripe rust pathogen, and the relatively avirulent isolates could evolve by mutation and/or somatic hybridization into more virulent races to infect cereal cultivars. Further studies are needed to test the hypothesis. Thus, stripe rust surveys and monitoring should pay more attention to grasses, as well as cereal crops. For the management of stripe rust, it should be helpful to control grasses in cereal fields and reduce susceptible grasses around crops. As many grass species are hosts of $P$. striiformis f. sp. tritici and/or P. striiformis f. sp. hordei, genes introgressed from these grasses to wheat and barley for resistance to stripe rust may not be considered as nonhost resistance. Such genes can be race specific, and their resistance may not be durable.

\section{ACKNOWLEDGMENTS}

Mention of trade names or commercial products in this publication is solely for the purpose of providing specific information and does not imply recommendation or endorsement by the U.S. Department of Agriculture (USDA). USDA is an equal opportunity provider and employer. This research was supported by the USDA, Agricultural Research Service (Project 534822000-015-00D) and Washington State University (Project 13C-3061-3925; 13C-3061-5665) PPNS 0651, Department of Plant Pathology, College of Agricultural, Human, and Natural Resource Sciences, Agricultural Research Center, HATCH Project WNP00663, Washington State University, Pullman 99164-6430. We thank M. Wang for technical support of the rust DNA extraction; L. Penman and A. Wan for increasing urediniospores and identifying races for some of the stripe rust isolates used in this study; R. A. McIntosh and C. Qualset for their help in stripe rust collection in California; R. A. McIntosh for reviewing an early version of the manuscript and his valuable suggestions; and S. Hulbert, T. Peever, and K. Gill for critical review of the manuscript.

\section{LITERATURE CITED}

Abbasi, M., Hedjaroude, G., Scholler, M., and Goodwin, S. B. 2004. Taxonomy of Puccinia striiformis s.1. in Iran. Rostaniha 5:71-82, 199-224.

Ali, S., Gladieux, P., Leconte, M., Gautier, A., Justesen, A. F., Hovmøller, M. S., Enjalbert, J., and de Vallavieille-Pope, C. 2014a. Origin, migration routes and worldwide population genetic structure of the wheat yellow rust pathogen Puccinia striiformis f. sp. tritici. PLoS Pathog. 10:e1003903.

Ali, S., Gladieux, P., Rahman, H., Saqib, M. S., Fiaz, M., Ahmed, H., Leconte, M., Gautier, A., Justesen, A. F., Hovmøller, M. S., Enjalbert, J., and de Vallavieille-Pope, C. 2014b. Inferring the contribution of sexual reproduction, migration and off-season survival to the temporal maintenance of microbial populations: A case study on the wheat fungal pathogen Puccinia striiformis f. sp. tritici. Mol. Ecol. 23:603-617.

Aljanabi, S. M., and Martinez, I. 1997. Universal and rapid salt-extraction of high quality genomic DNA for PCR-based techniques. Nucleic Acids Res. 25:4692-4693. 
Anderson, R. M., and May, R. M. 1982. Coevolution of hosts and parasites. Parasitology 85:411-426.

Bahri, B., Leconte, M., de Vallavieille-Pope, C., and Enjalbert, J. 2009a. Isolation of ten microsatellite loci in an EST library of the phytopathogenic fungus Puccinia striiformis f. sp. tritici. Conserv. Genet. 10:1425-1428.

Bahri, B., Leconte, M., Ouffroukh, A., De Vallavieille-Pope, C., and Enjalbert, J. 2009b. Geographic limits of a clonal population of wheat yellow rust in the Mediterranean region. Mol. Ecol. 18:4165-4179.

Beerli, P. 2009. How to use migrate or why are Markov chain Monte Carlo programs difficult to use? Conserv. Biol. 17:42-79.

Bever, W. M. 1934. Physiologic specialization in Puccinia glumerum in the United States. Phytopathology 24:686-688.

Brown, W. M., Jr., Hill, J. P., and Velasco, V. R. 2001. Barley yellow rust in North America. Annu. Rev. Phytopathol. 39:367-384.

Carleton, M. A. 1915. A serious new wheat rust in this country. Science 42:58-59.

Chen, C. Q., Zheng, W. M., Buchenauer, H., Huang, L. L., Lu, N. H., and Kang, Z. S. 2009. Isolation of microsatellite loci from expressed sequence tag library of Puccinia striiformis f. sp. tritici. Mol. Ecol. Resour. 9:236-238.

Chen, X. M. 2005. Epidemiology and control of stripe rust [Puccinia striiformis f. sp. tritici] on wheat. Can. J. Plant Pathol. 27:314-337.

Chen, X. M. 2007. Challenges and solutions for stripe rust control in the United States. Aust. J. Agric. Res. 58:648-655.

Chen, X. M. 2014. Integration of cultivar resistance and fungicide application for control of wheat stripe rust. Can. J. Plant Pathol. 36:311-326.

Chen, X. M., and Line, R. F. 1992a. Identification of stripe rust resistance genes in wheat genotypes used to differentiate North American races of Puccinia striiformis. Phytopathology 82:1428-1434.

Chen, X. M., and Line, R. F. 1992b. Inheritance of stripe rust resistance in wheat cultivars used to differentiate races of Puccinia striiformis in North America. Phytopathology 82:633-637.

Chen, X. M., Line, R. F., and Leung, H. 1993. Relationship between virulence variation and DNA polymorphism in Puccinia striiformis. Phytopathology 83:1489-1497.

Chen, X. M., Line, R. F., and Leung, H. 1995. Virulence and polymorphic DNA relationships of Puccinia striiformis f. sp. hordei to other rusts. Phytopathology 85:1335-1342.

Chen, X. M., Moore, M., Milus, E. A., Long, D. L., Line, R. F., Marshall, D., and Jackson, L. 2002. Wheat stripe rust epidemics and races of Puccinia striiformis f. sp. tritici in the United States in 2000. Plant Dis. 86:39-46.

Chen, X. M., Penman, L., Wan, A. M., and Cheng, P. 2010. Virulence races of Puccinia striiformis f. sp. tritici in 2006 and 2007 and development of wheat stripe rust and distributions, dynamics, and evolutionary relationships of races from 2000 to 2007 in the United States. Can. J. Plant Pathol. 32:315-333.

Chen, X. M., Wang, M. N., Wan, A. M., Cheng, P., and Cheng, J. J. 2012. Sexual or asexual reproduction, which one is more important for stripe rust? Pages 36-37 in: Disease Risk and Food Security. Proceedings of the 13th International Cereal Rusts and Powdery Mildews Conference. W.-Q. Chen, ed. China Agricultural Science and Technology Press, Beijing, China.

Cheng, P., and Chen, X. M. 2014. Virulence and molecular analyses support asexual reproduction of Puccinia strifformis f. sp. tritici in the U.S. Pacific Northwest. Phytopathology 104:1208-1220.

Cheng, P., Chen, X. M., Xu, L. S., and See, D. R. 2012. Development and characterization of expressed sequence tag-derived microsatellite markers for the wheat stripe rust fungus Puccinia striiformis f. sp. tritici. Mol. Ecol. Resour. 12:779-781.

Dietz, S. M., and Hendrix, J. W. 1962. Reactions of grasses to stripe rust at Pullman, Washington. Phytopathology 52:730.

Duan, X., Tellier, A., Wan, A., Leconte, M., de Vallavieille-Pope, C., and Enjalbert, J. 2010. Puccinia striiformis f. sp. tritici presents high diversity and recombination in the over-summering zone of Gansu, China. Mycologia 102:44-53.

Enjalbert, J., Duan, X., Giraud, T., Vautrin, D., de Vallavieille-Pope, C., and Solignac, M. 2002. Isolation of twelve microsatellite loci, using an enrichment protocol, in the phytopathogenic fungus Puccinia striiformis $\mathrm{f}$. $\mathrm{sp}$. tritici. Mol. Ecol. Notes 2:563-565.

Enjalbert, J., Duan, X., Leconte, M., Hovmoller, M. S., and de Vallavieille-Pope, C. 2005. Genetic evidence of local adaptation of wheat yellow rust (Puccinia striiformis f. sp. tritici) within France. Mol. Ecol. 14:2065-2073.

Eriksson, J. 1894. Uber die Spezialisierung des Parasitismus bei den Getreiderostpilzen. Ber. Dtsch. Bot. Ges. 12:292-331.

Hassebrauk, K. 1965. Nomenklatur, geographische verbreitung und wirtsbereich des gelbrostes, Puccinia striiformis West. Mitteilungen aus der Biologischen Bundesanstalt für Land- und Forstwirtschaft. Berlin-Dahlem 116:1-75.

Holtz, M. D., Kumar, K., Zantinge, J. L., and Xi, K. 2014. Genetic diversity of Puccinia striiformis from cereals in Alberta, Canada. Plant Pathol. 63:415-424.

Hovmøller, M. S., and Justesen, A. F. 2007. Rates of evolution of avirulence phenotypes and DNA markers in a northwest European population of Puccinia striiformis f. sp. tritici. Mol. Ecol. 16:4637-4647.
Hovmøller, M. S., Justesen, A. F., and Brown, J. K. M. 2002. Clonality and long-distance migration of Puccinia striiformis $\mathrm{f}$. sp. tritici in north-west Europe. Plant Pathol. 51:24-32.

Hovmøller, M. S., Sorensen, C. K., Walter, S., and Justesen, A. F. 2011. Diversity of Puccinia striiformis on cereals and grasses. Annu. Rev. Phytopathol. 49:197-217

Jin, Y., Szabo, L. S., and Carson, M. 2010. Century-old mystery of Puccinia striiformis life history solved with the identification of Berberis as an alternate host. Phytopathology 100:432-435.

Line, R. F. 2002. Stripe rust of wheat and barley in North America: A retrospective historical review. Annu. Rev. Phytopathol. 40:75-118.

Line, R. F., and Qayoum, A. 1992. Virulence, aggressiveness, evolution, and distribution of races of Puccinia striiformis (the cause of stripe rust of wheat) in North America, 1968-1987. USDA Bull. 1788.

Liu, B., Chen, X. M., and Kang, Z. S. 2012. Gene sequences reveal heterokaryotic variations and evolutionary mechanisms in Puccinia striiformis, the stripe rust pathogen. Open J. Genom. 1:1-14.

Liu, M., and Hambleton, S. 2010. Taxonomic study of stripe rust, Puccinia striiformis sensu lato, based on molecular and morphological evidence. Fungal Biol. 114:881-899.

Manners, J. G. 1960. Puccinia striiformis Westend. var dactylidis var. nov. Trans. Br. Mycol. Soc. 43:65-68.

Marshall, D., and Sutton, R. L. 1995. Epidemiology of stripe rust, virulence of Puccinia striiformis f. sp. hordei, and yield loss in barley. Plant Dis. 79:732-737.

Mboup, M., Leconte, M., Gautier, A., Wan, A. M., Chen, W., de Vallavieille-Pope, C., and Enjalbert, J. 2009. Evidence of genetic recombination in wheat yellow rust populations of a Chinese oversummering area. Fungal Genet. Biol. 46:299-307.

Nelson, R. J., Baraoidan, M. R., Vera Cruz, C. M., Yap, I. V., Leach, J. E., Mew, T. W., and Leung, H. 1994. Relationship between phylogeny and pathotype for the bacterial blight pathogen of rice. Appl. Environ. Microbiol. 60: 3275-3283.

Niu, Y. C., Li, Z. Q., and Shang, H. S. 1991. Puccinia striiformis West. f. sp. leymi and f. sp. elymi, two new formae speciales. Acta Univ. Agric. Boreali. Occident. 19:58-62.

Peakall, R., and Smouse, P. E. 2012. GenAlEx 6.5: Genetic analysis in Excel. Population genetic software for teaching and research-An update. Bioinformatics 28:2537-2539.

Rodriguez-Algaba, J., Walter, S., Sorensen, C. K., Hovmøller, M. S., and Justesen, A. F. 2014. Sexual structures and recombination of the wheat rust fungus Puccinia striiformis on Berberis vulgaris. Fungal Genet. Biol. 70:77-85.

Roelfs, A. P., Huertaespino, J., and Marshall, D. 1992. Barley stripe rust in Texas. Plant Dis. 76:538

Rohlf, F. J. 2008. NTSYSpc: Numerical Taxonomy System, ver. 2.20. Exeter Publishing Ltd., Setauket, NY.

Schuelke, M. 2000. An economic method for the fluorescent labeling of PCR fragments. Nat. Biotechnol. 18:233-234.

Steele, K. A., Humphreys, E., Wellings, C. R., and Dickinson, M. J. 2001. Support for a stepwise mutation model for pathogen evolution in Australasian Puccinia striiformis f. sp. tritici by use of molecular markers. Plant Pathol. 50:174-180.

Stubbs, R. W. 1985. Stripe rust. Pages 61-101 in: The Cereal Rusts, Vol. 2, Diseases, Distribution, Epidemiology and Control. A. P. Roelfs and W. R. Bushnell, eds. Academic Press, New York.

Tollenaar, H. 1967. A comparison of Puccinia striiformis f. sp. poae on bluegrass with P. striiformis f. sp. tritici and f. sp. dactylidis. Phytopathology 57:418-420.

Wan, A. M., and Chen, X. M. 2012. Virulence, frequency, and distribution of races of Puccinia striiformis f. sp. tritici and P. strifformis f. sp. hordei identified in the United States in 2008 and 2009. Plant Dis. 96:67-74.

Wan, A. M., and Chen, X. M. 2014. Virulence characterization of Puccinia striiformis f. sp. tritici using a new set of $Y r$ single-gene line differentials in the United States in 2010. Plant Dis. 98:1534-1542.

Wang, M. N., and Chen, X. M. 2015. Barberry does not function as an alternate host for Puccinia striiformis f. sp. tritici in the U.S. Pacific Northwest due to teliospore degradation and barberry phenology. Plant Dis. 99:1500-1506.

Wang, M. N., Wan, A. M., and Chen, X. M. 2015. Barberry as alternate host is important for Puccinia graminis f. sp. tritici but not for Puccinia striiformis f. sp. tritici in the U.S. Pacific Northwest. Plant Dis. 99:1507-1516.

Wellings, C. R., Burdon, J. J., McIntosh, R. A., Wallwork, H., Raman, H., and Murray, G. M. 2000. A new variant of Puccinia striiformis causing stripe rust on barley and wild Hordeum species in Australia. Plant Pathol. 49:803.

Zhan, G. M., Chen, X. M., Kang, Z. S., Huang, L. L., Wang, M. N., Wan, A. M., Cheng, P., Cao, S. Q., and Jin, S. L. 2012. Virulence and molecular comparison of Puccinia striiformis f. sp. tritici populations in China and the United States. Fungal Biol. 116:643-653.

Zhao, J., Wang, L., Wang, Z. Y., Chen, X. M., Zhang, H. C., Yao, J. N., Zhan, G. M., Chen, W., Huang, L. L., and Kang, Z. S. 2013. Identification of eighteen Berberis species as alternate hosts of Puccinia striiformis f. sp. tritici and virulence variation in the pathogen isolates from natural infection of barberry plants in China. Phytopathology 103:927-934. 